\title{
The politics of accountability
}

\author{
Jenny Ozga ${ }^{1}$ \\ Published online: 5 December 2019 \\ (c) The Author(s) 2019
}

\begin{abstract}
This paper draws on recent research in Europe and England to discuss the politics of accountability. It is suggested that, as policies in education are increasingly focused on delivering technical-managerial accountability, that is accountability understood as evidenced in international, national, institutional and individual comparative measures of performance, so the shifting power relations of system redesign supported by data use are concealed and suppressed. System redesign is promoted by 'networked' governance and the de-centred state, in institutional 'freedom' from bureaucracy, in the de-professionalisation of public sector workers, in the proliferation of managers, in the redefinition of citizens as consumers. The implications of such reforms for politics are profound, as political legitimacy is a fundamental precondition for the sustainability of the welfare state and welfare state organizations are dependent on active political processes of producing legitimacy and political accountability.
\end{abstract}

Keywords Politics $\cdot$ Accountability $\cdot$ Data $\cdot$ Governance

\section{Introduction: the politics of policy}

The term accountability is much discussed: there are competing definitions in a variety of literatures, from political science, organisational studies and education: indeed Bovens (2007) suggests that it is necessary to clearly distinguish between normative and mechanistic uses of the term, in order to reduce confusion. In the field of education, scholars further identify different forms of accountability. For example, Ball et al. (2012) distinguish between market accountability that is achieved through provision of services and financial management and political accountability that involve direct contact with voters and responsiveness through elected officials. Olssen and Peters (2005) differentiate bureaucratic-professional accountability based

Jenny Ozga

jennifer.ozga @education.ox.ac.uk

1 Department of Education, The University of Oxford, 15 Norham Gardens, Oxford OX2 6PY, UK 
on expertise consumer-managerial accountability based on market standards and externally defined objectives. More recent research has explored theuses of accountability in legitimating increased regulation of teachers (Mausethagen 2013) and the role of accountability practices in developing capacity (Stitzlein 2015). The range of approaches is very considerable.

Rather than attempt to summarise different usages of the term, this paper works with Raymond Williams' practice of challenging the 'nominal continuity' of the meanings of what he termed 'Keywords' by focussing on their 'radically different' or 'radically variable' meanings (Williams 1988: 17), emphasising how meanings change in relation to who is using specific terms, in what circumstances and conditions, and with what purposes. This approach to definition is political:

... it is necessary to insist that the most active problems of meaning are always primarily embedded in actual social relationships, and that both the meanings and the relationships are typically diverse and variable, within the structures of particular social orders and the processes of social and historical change. (1988: 21-22).

Williams thus draws our attention to the power relations embedded in and reflected in defining meanings, and it is the necessity of being attentive to those power relations that I refer to in discussing the politics of accountability here. The discussion of politics, I suggest, is largely absent from much scholarly work on accountability in education, where accountability policies is understood as given, as existing in the world as concrete, objective entities that reflect the decisions of rational authority and that then have effects in terms of action to solve problems and produce agreed solutions. In this perspective on policy, there is the assumption of a linked, but distinct, sequence of events, a linear process, through which policy is made: from analysis of the problem and reviewing responses, to selection of the best, evidence-based approach, to implementation of the chosen course of action, and finally, evaluation of its success, with the intention of further improvement based on lessons learned. These are approaches that exclude politics, and that limit policy to the formal mechanisms of government and official political actors. Such formal and rather static definitions of policy and policy making, associated with the more traditional versions of political science, reflected, and continue to reflect, the concerns of political scientists to improve the development and implementation of public policy. These ideas were and are extremely powerful, especially in the US, where the history of the field of political science, with its emphasis on legislative actions and decision-making, and its continued disciplinary strengths, reinforced by a competitive academic culture, continues to act as a 'straitjacket ... [so that] to imagine policy in a new way has not been easy' (Yanow 2011: 305-306)

Alternative perspectives place the emphasis on policy as process and draw attention to the contested politics that have shaped education policy in the struggles over what constitutes public education. Such approaches are historicallyinformed, drawing attention to the ways in which the redesign of systems of education have always been central to the work of nation-state building, and to the sometimes contradictory aims of promoting citizenship, generating economic 
productivity, sustaining (selected) cultures and enabling social inclusion (Novoa and Yariv-Maschal 2003; Ozga 2000; Green 1990). In this definition of policy, it is generated, promoted and contested in multiple sites, involving teachers, parents and pupils as well as governments and their agents. It requires attention to the context of power, social structures and relationships and discourses around education in both national and global contexts. Seeing policy as politics focuses on how state policy in its design and attempted delivery involves politics, through interests, conflicts, power and control-so that politics is an essential element of policy:

This opens policy up to the appropriate participation of all those involved through points of conception, operational formulation, implementation, delivery on the ground, consumption and evaluation, rather than separating policy from politics, which has the effect of protecting and sustaining bureaucratic logics of practice from democratic possibilities (Ozga and Lingard 2007: 67).

The erosion or suppression of democratic possibilities through the installation of managerial-technical forms of accountability is the primary concern of this paper. I draw on a body of research (details below) to argue that the ideological 'project' of welfare or public sector reform has installed particular principles of system design-of institutions and of governance itself-across Europe and beyond, and this redesign has real consequences for people working in schools and education institutions, and for how they are able to act politically to defend their interests and mediate policy 'scripts'.

These principles of redesign are associated with neo-liberalism: characterised by the adoption of market-based solutions within governance, and by extension within a range of institutions and practices deemed 'public' in the previous liberal welfare state settlements, such as education (Connell 2013). 'Reform' of the public is pursued through market competition, privatisation, managerialism, competitive standardised testing, data-driven accountability measures, performance measurement and financial devolution in the context of reduced central funding. System redesign reflects a range of principles that are expressed in the idea of 'networked' governance and the de-centring of the state, in institutional 'freedom' from bureaucracy, in the de-professionalisation of public sector workers, in the proliferation of managers, in the redefinition of citizens as consumers.

In its managerial-technical form, as Newman and Clarke suggest, accountability has been adopted internationally as part of the conception of information or evidence-based 'good governance' in which transparency, participation and performance are combined (see Newman and Clarke 2009: 100-102), and where accountability through democratically-elected representatives is largely absent.The widespread promotion of accountability in its managerial-technical form as part of international agendas promoting particular definitions of 'good governance' (see, for example, Fazekas and Burns 2012) is highly dependent on growth of data use and capacity-in education and across public sector service provision. Data are crucial to creating and distributing particular meanings of 
accountability, data-based regulatory instruments support this market, technical and performance-based version of accountability: data and data systems construct policy problems and frame policy solutions beyond and across the national scale (Novoa and Yariv-Maschal 2003; Ozga 2009 Grek and Ozga 2010; Carter and Lawn 2015; Lawn and Normand 2015).

The implications of such developments for politics are profound, as political legitimacy is a fundamental precondition for the sustainability of the welfare state (Laegrid and Mattei 2013) and welfare state organizations are dependent on active political processes of producing legitimacy and political accountability. Politics are thus central to debates on accountability and cannot be treated as separate from considerations of the effectiveness or otherwise of administrative and managerial changes. It is important to note that the production of legitimacy is understood here as a governing practice: the intention is not to invoke nostalgia for a lost golden age of democratic participation in policy making in education, but to highlight the significance of the shift away from governing through political institutions (where power relations are unequal but the possibility of contestation remains open) to governing practices that steer and mediate individual actions, and conceal and thus suppress politics.

In the next section of the paper I provide brief background information on the research on which this paper draws, and a summary of findings from that research, especially in relation to data use.

\section{The research 'project'}

The research on which this paper draws was carried out, with colleagues, between 2000 and 2017, ${ }^{1}$ and continues, in different forms, though now largely unfunded. It followed an agenda of enquiry framed by curiosity about how governing education was 'done' in globalizing times, especially in Europe, and looked in turn at three key aspects of the puzzle: (1) the growth of education as a key policy field in Europe (and especially the work of the European Commission) (2) the growth or regulatory instruments (especially data) in education and their national and transnational effects (3) the work of national and transnational policy actors in doing governing in the European education policy space. The research was carried out through interviews with policy actors at different 'levels' in a range of European contexts, (i.e. transnational, national and institutional), surveys of policy practitioners, and documentary analysis. More information on the methodology and findings from the research can be found in Grek et al. (2009), Grek and Ozga (2012) Grek and Lindgren (2014).

\footnotetext{
1 Funded projects include: ESRC RES-062-23-2241 'Governing by Inspection: Inspection and the Governing of Education in England, Scotland and Sweden', EC FP 6 (IP 028848-2) 'KNOWANDPOL: The role of knowledge in the construction and regulation of health and education policy in Europe' and ESRC RES-000-23-1385: 'Governing by Numbers: data and Education Governance in Scotland and England'.
} 
Our overarching conclusions of the research, briefly summarized, were that, throughout Europe, the governing of education has changed from traditional, hierarchical and bureaucratic forms to more horizontal, networked and distributed forms involving new political actors; that these governing assemblages of people and practices are held together by the meaning-making activities of political actors who work in them; that, in education, meaning-making is concentrated around data-based and comparative knowledge, that is used to promote 'cognitive consensus' about policy directions; that cognitive consensus is based on a dominant narrative of technical capacity and capability through which comparative data analysis produces 'levers for action' (Grundmann and Stehr 2012) which constitute 'a condensed form of knowledge about social control and ways of exercising it' (Lascoumes and le Gales 2007), and finally, that all these developments have problematic consequences for the politics of education, in that they combine to erase the political from the governing of education, obscuring the interplay and conflict of different interests and masking the operation of power relations.

In other words, changes from government to governance in new networked forms, that appear to be less hierarchical and to involve new actors, combined with databased instruments, act to redefine political relations by:

..... orienting relations between political society (via the administrative executive) and civil society (via its administered subjects) through intermediaries in the form of devices that mix technical components (measuring, calculating the rule of law, procedure) and social components (representation, symbol). (Lascoumbes and Le Galès 2007: 6)

The instruments of data collection and analysis, including those that support technical accountability (for example the PISA tests, or the attainment targets set by the UK Department for Education) invoke scientific and technical rationality, which combine to support their legitimacy and neutralize their political significance. Criticism and contestation tend to cluster around the choice and design of the instruments, thus concealing the absence of more fundamental debates, obscuring the political character of these instruments, the governing work that they do, and contributing to the cognitive consensus on policy. These data are public and said to be 'transparent'. They are no longer produced for and distributed among the bureaucratic elite but distributed and doing political work in the wider population, not only for politicians and civil servants. They have what Nellie Piattoeva calls 'popular and official currency' (Piattoeva 2014). Public rankings, league tables, PISA results are both official and popular knowledge forms.

The availability and rapid distribution of data in many different forms is promoted by international organisations as a driver and enabler of participatory governance. Social media are said to reach a broader set of actors, often those excluded from traditional politics, and to enable more open and representative public consultations. Proponents of social media point to its capacity to educate young people about the world in direct and appealing ways, and to develop their capacities for navigating in that world. They point to the increasing regulation of data use, and its progressive potential. Critics are concerned about the influence of big data providers (Williamson 2017). Social media can be used to put 
direct and instant pressure on schools and officials: indeed our research revealed increasing concern among policy actors about managing social media in such a way as to reinforce policy impact. Social media use may increase pressure for short-term policy change, however advocates of stakeholder involvement through the distribution of information argue that it creates a shared responsibility that strengthens accountability in the system (Burns and Köster 2016). Problems, they suggest, will be solved, indeed the involvement and engagement of a diverse group of actors ensures:

that educational governance will be able to continue to evolve along with our societies and schools. There is thus a need for mechanisms to include all stakeholders and voices (not only the most vocal or technologically savvy) in the governance process, and to design ways to strengthen participatory governance mechanisms. This will also require working with less active or less confident stakeholders to build capacity and empowerment to enable them to take part in the process. (Burns and Köster 2016: 13)

Yet, as more critical commentators have observed, this is performance rather than participation in which politics is reduced to public spectacle, or 'audience democracy' (Manin 1997) in which politics is diminished and through which consumercitizens are positioned as spectators, without agency:

Politics is influenced, and in a certain sense constructed, through a systematic exposure to surveys, questionnaires and other means of data collection that would, or are perceived to have the ability to, estimate 'public opinion'. This ongoing collection, production and publication of surveys leads to an 'instant democracy', a regime of urgency that provokes a permanent need for self-justification’. (Novoa and Yariv-Maschal 2003: 427)

To summarise, with attention to the issues of accountability and politics, the research on which I draw here highlights the erosion of debate and conflict, so characteristic of past struggles over public education (Lawn 1996; Ozga 2000), and their concealment though reconfiguration of state functions: as Rose and Miller (2010) put it: [through a re-coding of] 'the locus of the state in the discourse of politics' through changing the governing practices operating between the state, private agents and the market, through the discursive construction of this development as rational and coherent, and through installing a range of practices that seek to govern economic life, public management, health provision, welfare policy and education. As Piattoeva (2014) argues, these practices, including practices of accountability, need to be recognised as doing political workfor example enabling and consolidating control over a wide network of actors and institutions-local authorities, schools and teachers included. The 'popular' work they do is make connections to individual citizens/learners/pupils is such a way as to steer of mediate their decisions and actions in the economy, family sphere and any other aspect of everyday life, including, for example, in education, in choice of school, curriculum choices, or choice of employment. This work is 'popular' because it displaces attention from structural factors such as 
'the system' or economic context as limiting or enabling factors in determining or enabling 'choice', and places responsibility on the individual learner and consumer of opportunity.

In the next section I report in more detail on some of the research on PISA that was carried out within the overarching 'project' referred to above.

\section{Knowledge, policy, politics}

Our research agenda included attention to PISA as a powerful, knowledge-based regulatory instrument. Our findings illustrated its significance in building consensus through comparison, ordering and meaning-making within the framework of accountability understood as performance-based reporting. Here I draw on the specific project ['KNOWANDPOL: The role of knowledge in the construction and regulation of health and education policy in Europe'], although PISA also featured in research beyond that project but within the overarching agenda of enquiry. The EC funded project KNOWANDPOL was carried out between 2006 and 2011 in eight European countries, and contained a number of comparative case studies of significant policy instruments, including PISA (for details see Delvaux and Mangez 2008). The use of PISA in six national contexts in Europe was examined using a shared set of research methods including extensive documentary analyses of relevant PISA instruments and reports along with interviews with politicians, analysts and professionals and with the PISA secretariat. Comparative analysis showed PISA to be a very powerful policy instrument that is able to penetrate different kinds of policy-making regimes and very diverse political circumstances, because of its high level of credibility and trustworthiness as the 'gold standard' of performance assessment, and because of its apparent adaptability to many disparate political ends (Grek et al. 2009). A further element of the research consisted of a meta-analytical overview of PISA that explored the selection by policy makers of issues from the massive data base on education performance that PISA generates. Three modes of PISA knowledge use were identified: (1) as a basis for knowledge-based analyses of specific issues on the policy agenda; (2) as a source for studies of national education 'problems'; and (3) as a resource for improving domestic regulation tools-in particular accountability mechanisms and quality assurance policies. PISA knowledge was mobilised to support the legitimacy of specific education policies within a broad policy framework, promoted by the European Commission, of enhanced economic competitiveness, as other commentators have noted (Lawn and Grek 2012: 104-105).

The nation-states participating in PISA and studied in our research engage actively with this regulatory instrument despite the threat that PISA may pose to the nation-state's capacity to act independently in the governing of its education system. This engagement requires the building of consensus about how problems are translated into national contexts (Piattoeva 2015) through the creation of consensus and the incorporation and dissemination of ways of thinking and acting that draw policy makers into monitoring and mutual surveillance of education systems-practices that define their new identities and roles as system managers, 
operating within a technical-managerial form of accountability. PISA texts enable policy-makers to underline the rationality and scientific basis of their actions; to embrace modernization agendas that break away from national traditions, and to see their system's performance in comparative terms within a European and global competitive space-all these things enable them to 'move' their education systems to the (imagined) future (Grek 2012; Bieber et al. 2015).

Whatever the use to which PISA is put, it is not a form of political accountability, instead, through the politics of mutual accountability and the international spectacle (Novoa and Yariv-Maschal 2003), it creates acceptance and indeed reliance on a new form of knowledge-based regulation tool, which requires a specific kind of knowledge: simplified, comparative, normative, transportable. These were our findings in 2006-2011, and it is important to note the fact that we found that systems with strong narratives about their purposes and traditions were more resilient in responding to PISA results (Ozga 2017). It is also, of course, quite possible that other contexts of enquiry might produce different results, for example recent literature draws attention to China's measured response to PISA 2015 (Tan 2017) and Grek has noted the possibly diminishing effects of PISA shock (Grek 2017).

A further finding from our research on PISA was the shift in political influence away from politicians and towards non-governmental actors, especially external experts, commercial agencies and consultants. At the same time, because-in the shadow of PISA-so many sources of knowledge and information have become available, the issue of interpretation of performance-related data becomes paramount. We found evidence to support Grundmann and Stehr's identification of the tendency to simplify complex knowledge and information in order to arrive at a basis for action, and of the growing role of experts and consultants in doing this:

'The rapid growth of experts, advisers and consultants in education arises from the rapid expansion of knowledge/information, this provides opportunities for simplification of the problem of endless competing interpretation in order to provide a basis for action' (Grundmann and Stehr 2012: 20-21).

These experts are:

'more than the diffusers of ideas; they develop conceptual knowledge in order to promote educational reforms, drawing on their substantial experience as policy advisers to governments and IOs'.

\section{Moreover:}

'their attributes as experts and consultants tend to obscure the ideological and political dimension of their activities of knowledge production for policy' (Shiroma 2014: 2).

The political nature of that interpretation is often concealed, as Shiroma points out, because the label 'expert' confers scientific status and authority. Our research revealed the ways in which much of the activity around data involves the 
application of rules, standards and processes stored in algorithims and technical fomulae that mobilise the particular preferences of their creators and are applied without explicit reference to the choices they contain (Higgins and Lerner 2012: 7). Data analysts talked about making data intelligible to policy makers, about simplifying complexity. As Williamson (2017: 4) puts it: 'Digital software technologies, data systems and the code and algorithms that enact them have become powerful yet largely hidden influences in the governing of education.'

The growth of this form of expertise is recognised as a transnational phenomenon, with experts increasingly working between national and transnational arenas, and claiming status as a 'new governing elite' (Stone 2013: 41; Lawn and Grek 2012: 75), also described as a 'magistracy of influence' (Lawn and Lingard 2002: 292) and a new 'European technocracy' (Normand 2016: 129). The authority of science is invoked to sustain their position, but, as Dale points out, the idea of science that is invoked here fails to acknowledge that 'scientific authority' is not monolithic, but arises from debate and dispute, and does not in itself ensure acceptance of models, without reference to 'the set of political conditions' under which they are advanced (Dale 2000: 445). Nor is it attentive to the related recognition that scientific knowledge is produced, accepted and contested in specific political contexts (Connell 2007; Demszky and Nassehi 2014).

To summarise, the erosion and concealment of politics that is produced by technical-managerial versions of accountability, also enables a technocratic elite to accrue power and influence in education, to profit from its provision, and to pursue political agendas that appear to be neutral, objective and necessary.

In the next section I look in more detail at the changing policy context of England, which often appeared as an 'outlier' in our research, going further and more rapidly in the dismantling of established institutional structures and practices than did other European systems, perhaps especially in adopting technical-managerial forms of accountability (Ozga 2009, 2016; Ozga et al. 2011). I identify a shift in system design from a hierarchical, stable organization that linked schools as institutions directly to local government and thence to the centre, to a fragmented, fractured and dis-integrated 'system' of provision, and consider the implications for education politics.

\section{Accountability in a system of systems?}

Accountability in its technical-managerial form was most highly visible in our research in the context of England, which has claimed 'world class' status on the basis of its sophisticated instruments of performance management in education, and, in particular, its data systems, since the 1990s. The governing of England is now organised in networks where public-private hybrids offer education services, provision is shaped by parental choice and other new public management methods. In the 1980s and 1990s, England adopted deregulation through enhanced institutional autonomy and school-based management along with enhanced parental choice of school and competition between schools to a greater degree than the European systems that we studied, and, indeed, to a greater degree than its neighbour, Scotland. 
Decentralisation and devolution were pursued with the aim of enabling the market to operate effectively. The reliance on market mechanisms reflected policy commitments to shrinking the state and redefining the citizen as consumer with responsibility for making informed choices, based on widely distributed information (Newman and Clarke 2009). Policy and provision were distributed or decentralised to a range of actors and agencies, including, in some cases, private companies (Ball and Junemann 2012). The idea of political or democratic accountability was absent from the discussion of these developments, in contrast to debates in some Nordic systems-especially Denmark (Andersen and Dahler-Larsen 2007). Instead the case was made with reference to efficiency, the need to improve teacher performance through regulation and the assumption of improved performance following from increased responsiveness to consumers.

This policy direction was maintained throughout the 2000s though the setting of national targets and performance indicators and the monitoring of local performance through national inspectorates, including the Office for Standards in Education (Ofsted). Output monitoring was the means of delivering consumer and market forms of accountability, despite their inadequacy in ensuring democratic participation in priority setting for social outcomes (Institute for Public Policy Research 2001). Moreover, the dependency created by central regulation, especially through data use, established patterns of interaction between the centre, the locality and the schools that strengthened key elements of managerial accountability or 'answerability' (Ranson 2003).

In this way the possibility of building political accountability around social goals and democratic processes was reduced. Local government was profoundly reshaped through the continued influence of the centre on data production and use and the restriction of the role of Local Education Authorities (LEAs) to that of data provider (Ozga et al. 2011) Data, then, remain central to the governing work of education in England, indeed there is to be much more data, freely available to parents and others-much more transparency and unmediated information is promised. Government presents policy as informed, justified and legitimated by data and constructed and circulated an overarching narrative of knowledge-policy relations, and, in addition to home-grown data systems, global comparative data from OECD's PISA provides a key reference point.

The political act of reframing citizens as consumers (Newman and Clarke 2009) that is supported by data on school performance, is clearly illustrated in this extract from the UK Department for Education's White Paper in which 'direct accountability' is to be achieved through the provision of 'much more information' is to be made available to enable parental choice in an 'autonomous' school system:

In creating a more autonomous school system, we will reduce duties, requirements and guidance on all schools, and make sure that every school can, over time, enjoy the freedoms that Academies currently have. We will dismantle the apparatus of central control and bureaucratic compliance. We will instead make direct accountability more meaningful, making much more information about schools available in standardised formats to enable parents and others to assess and compare their performance. And, through freeing up the system, we 
will increase parents ability to make meaningful choices about where to send their children to school. (DfE 2010).

One of the people responsible for getting this information out in 'standardised formats' commented on the opportunities thus presented to commercial actors:

.......we're putting more information out all the time about the performance of schools-and that's another thing this government has done-to make all this data available-and part of the reason was to maximise commercial usage-commercial agencies were to come in and just use the data -if that becomes more regularly used and you get a kind of 'trip adviser' view of how schools are doing-you might think, well-that's pretty imperfect..... (Policy actor 01$)^{2}$

Because of the need to create diversity in provision-so that choice and competition can operate appropriately-the landscape of provision looks increasingly differentiated and involves new actors, including public-private hybrids, and new types of school, created in pursuit of 'freedom' from local authority control—so that almost half of all state secondary schools in England are now academy schools. Free Schools are also growing in number, these are all-ability state-funded schools set up 'in response to parental demand' by a wide range of proposers, including charities, universities, businesses and groups of parents. They operate under the same legal requirements as academies. As these types of provision increase, examinations and curricula are also changing in order to reflect policy priorities, however the speed of change in policy making in education in England, especially in the period 2010-2015, is making a complex situation even more complex. For example, changes in academisation policy brought with them major shifts in the requirements on sponsors and schools engaged in the process, to the extent that there was considerable confusion about which rules applied.

The Conservative-led coalition government established following the UK general election of May 2010 saw rapid growth in the number of schools becoming academies. This was made possible by the Academies Act of 2010, which was rushed through the UK Parliament in order to enable schools to opt for academy status by the start of the new academic year in September. This policy signalled the intention to move towards academy status for the majority of schools in England. The majority of these so-called converter academies are high performing schools. The policy shift was promoted as enabling autonomy, and freeing schools from local authority bureaucracy. This policy gathered momentum once a Conservative government was elected in 2015, indeed in October 2015, the then Prime Minister, David Cameron, told the Conservative Party conference that all schools should become academies. In March 2016 the Department for Education published a White Paper which stated that all state-funded schools in England would become academies by 2022, an announcement that provoked considerable opposition and led to some shift in the policy by allowing successful local authority schools to escape compulsion to move to academy status.

\footnotetext{
${ }^{2}$ We used the term Policy actor to refer to official policy makers (at international/transnational local and central government levels) across the different research projects that made up the overarching research work, and assigned them numerical codes in order to protect their identities.
} 
Academy governance has attracted controversy. Academy trusts have considerable power and may shape their decision-making structures more or less as they choose. There are two layers of academy governance: academy members, who sit at the top of the governance structure for a single-or multi-school academy trust, and trustees. The members, who can be as small as three in number-although the DfE recommends that there are at least five-have ultimate responsibility for ensuring that the trust achieves its objectives. In sponsored academies, the lead sponsor has the right to control the governing body by having the ability to appoint the majority of members. The trustees collectively act as the trust's governing body and must ensure it complies with company and charity law and with the trust's funding agreement with the Secretary of State (DfE 2015). In this respect, Academies may be seen as embodying the characteristics of network governance identified earlier, they are horizontal and distributed forms involving new political actors, often with commercial interests, and with no local representation of democratic oversight. These schools sometimes form multi-academy trusts, or MATs, but MATs themselves are single legal entities, and have one set of trustees. Their member schools operate under a single governance structure. Some MATs are very large, with 40 or more schools; yet these schools are directly responsible to the Secretary of State for Education-a situation summed up by one of our interviewees, a former HMSCI, as 'madness' (policy actor 07).

This extent of confusion brought about by the proliferation of types of provision is revealed by the DfE itself in the 2016 White Paper Educational Excellence Everywhere, which recognised the problem of variation in the operation of academies, especially in Funding Agreements which differ depending on when those agreements were signed. The White Paper stated that the Government will engage with existing sponsors, academies, dioceses and the wider schools sector to redesign the legal framework for academies, in order to "strike the right balance of freedoms for and controls over academies, with the aim that the new framework: (a). Protects and promotes autonomy, alongside robust and proportionate accountability and (b). Ensures that ministers are able to make and evolve policy that will apply equally to both past and future academies, particularly in urgent situations' (DfE 2016: 84).

Our research reveals considerable tensions between the different purposes and types of accountability - and, by extension-in governing processes, especially those where simultaneous regulation and de-regulation is evident. Attempts by the centre to recover or promote trust through more bottom up and self-generated forms of evaluation of performance are repeatedly undermined by the weight of the work of data production and use and the continued effects of managerial accountability on political or professional accountability (Grek and Lindgren 2014). They are also undermined by the absence of democratic accountability, in a chaotic environment of 'systems within systems', as this former senior civil servant suggests:

Historically we've all looked at that -that whole system-as being the responsibility largely if not exclusively of one agency-the local authority-I think what we're going to see is a system of systems within systems-a number of different players. I even ask the question whether it will be possible to talk about an education system in the future. Sub systems within national systems-some sub 
systems that will have really no role at all for a local authority -not for provision or democratic oversight-whatever that means. ... accountability is a huge issue-to whom are schools accountable is the question. Well you can answer that at different levels. You can say first and foremost you're accountable to the parents and the children who attend the school. And for quite a few Conservative politicians that's where you would end. You're not mediating accountability through elected politicians -you're saying here's a public service, being provided, people either chose to use it or they don't (Policy actor 01).

To summarise, then, our research in England revealed that, to a greater extent than in the other European systems in our studies, the lines of accountability were blurred by constant and quite radical system redesign. The English system of provision was no longer a system but 'a system of systems within systems': in such a situation 'accountability is a huge issue' but political accountability is absent, eroded by the multiplicity of providers and the absence of participation at institutional and local levels. In this redesign, accountability is located in the school and restricted to performance, with an overview at the centre provided by performance data.

\section{Discussion}

The research on which I have drawn in this paper always included a strong comparative element, and working with European colleagues across a range of contexts has underlined the need for historically informed and culturally-alert forms of enquiry (Ozga 2019). Our research in continental Europe identified key trends-as discussed above, these may be summarised as changes in governing practices, notably the influence of transnational agencies such as OECD and the EC, producing 'consensus' around policy directions, including accountability policies. We also identified the rapid growth of regulatory instruments, that enable technical-managerial accountability, and identified the growth of experts and analysts as powerful policy actors in education policy making in Europe. In the specific case of England, the speed and depth of change perhaps indicates that the post-war settlement was a break from established governing practices in education there: the rapid development of multiple providers and commercial interests in education marks a return to an established pattern that was disrupted by the post-war welfare settlement. The post-war system was characterised by those who ran it as a 'partnership' between the centre, local government and the organised teachers. It was constructed as part a national system 'under the control and direction' of the Minister, but that control and direction was dependent upon the Minister's guardianship of democratic principles, that required real partnership with local authorities, and teacher unions. The education service was decentralized and 'a large measure of power and responsibility should rest with democratically elected authorities ... as a safeguard against totalitarianism' (Wood 1946: 269) 
In post-war Britain (more accurately England) policy making relied on a claimed process of consensus about education (Musgrave 1970), though the nature of the consensus is open to debate (Lawn and Ozga 1986; Gewirtz and Ozga 1990). Democratic ideas were central to the discourse of the new social democratic settlement and were clearly antagonistic to authoritarian regimes. The core ideals of the new public services were that they had to be universal, comprehensive and engage the state and citizens in their organization (Shipman 1984 p30). A consequence of this new settlement was that the system was described in terms of power and responsibility, and most of all, as a service: it was to be organised to reflect or represent a balance of power between central government, the local education authorities and organized teachers (Lawn 2013).

The notion that policy making was better described as administration (Birley 1970) conveys the extent to which the politics of education was constructed and presented as restricted to party political difference, and managed within a fairly closed system-a policy community, in some accounts, a policy elite in otherswhich shared a set of implicit -and sometimes more explicit assumptions about how education should be governed, and how it should be organised. Although tensions between these 'partners' were acknowledged, they were characterised as binding the system in a 'triangle' in productive tension. This policy community reflected governing assumptions about mass education provision in the twentieth century. The model for schooling was industrial, and in the context of expansion of basic provision the use of bureaucratic and professional norms and practices to manage accountability was logical. National or local/municipal governments set (loose) guidelines for standards of curriculum content and attainment levels, credentialed professionals were expected to meet these standards, and central governments relied on their 'partners' in local government and the professions to provide a credible account of their efforts.

By the 1960s and into the 70s, the tension in the triangle had increased, especially as assumptions about the distribution of intelligence/capacity and wider social change produced demands for fairness and, increasingly, equality, of opportunity, first on the basis of class, later in relation to gender and ethnicity, that led to struggles between the 'partners' over the structures of schooling, and a shift in the politics of education that reflected a move away from joint problem solving and exposed fractures in the system. Political struggles over the shape of provision took place outside the formal structures and processes of the partnership: they involved teachers and local government workers, education researchers and parent organisations, education pressure groups and campaigners.

The Thatcherite response to this in the 1980s set out to eliminate the possibility of an oppositional politics of education through the gradual erosion of the local authority presence in education, through the evisceration of the teacher unions, and various reforms of teacher education, curriculum, school governance, all of which laid the groundwork for the current wave of systemic reforms. The elimination or hollowing out of the politics of education, then, is the result of the governing work that technical accountability and its adherents do-but also of a long process of attrition, in which potential political actors were disempowered, stigmatised and set in tension with the new education 'stakeholders'. 
These developments show that political legitimacy as 'a fundamental precondition for the sustainability of the welfare state' (Laegrid and Mattei 2013) has to be constructed and is susceptible to challenge and renegotiation. The current redesign of systems in England, including systems of accountability, has suppressed divergent narratives that conveyed meaning about values in contexts of multiple and possibly conflicting answerabilities (Ranson 2003).

In this situation, it is important to keep in mind Raymond Williams' insights into how meanings are made, and how Keywords may operate to express and disseminate very selective interpretations, including of accountability. This paper has drawn on recent research to illustrate how contestation of those selective interpretations by practitioners, parents and professionals is inhibited by the popular as well as the official currency that data have (Piattoeva 2014), along with a technical-managerial definition of accountability that restricts debate or dissent by presenting these devices (performance testing, league tables etc.) as carrying scientific authority and powerful symbolism. Together, these have the effect of disempowering the populations who use public services through their encouragement of individualism, and their redefinition of the citizens as consumers, and thus the politics of education is concealed or suppressed.

Acknowledgements The research drawn on in this paper was supported by the Economic and Social Research Council (ESRC) (Grant No. RES 06223 2241A), by the European Science Foundation and the ESRC (ESF/ESRC RES-000-23-1385) and by the European Commission (EU FP6 IP 028848-2).

Open Access This article is distributed under the terms of the Creative Commons Attribution 4.0 International License (http://creativecommons.org/licenses/by/4.0/), which permits unrestricted use, distribution, and reproduction in any medium, provided you give appropriate credit to the original author(s) and the source, provide a link to the Creative Commons license, and indicate if changes were made.

\section{References}

Andersen, V., \& Dahler-Larsen, P. (2007). The framing of public evaluation data. In R. Boyle, J. Breul, \& P.Dahler-Larsen (Eds.), Open to the public: Evaluation in the public arena New Brunswick. Transaction Books.

Ball, S., \& Junemann, C. (2012). Networks, new governance and education. Bristol: Polity Press.

Ball, S., Maguire, M., \& Braun, A. (2012). How schools do policy. Abingdon: Routledge.

Bieber, T., Niemann, D., \& Martens, K. (2015). Soft governance through PISA benchmarking. In M. Lawn \& R. Normand (Eds.), Shaping of European education: Interdisciplinary approaches. London: Routledge.

Birley, D. (1970). The education officer and his world. London: Routledge Kegan Paul.

Bovens, M. (2007). Analysing and assessing accountability: A conceptual framework. European Law Journal, 13(4), 447-468.

Burns, T., \& Köster, F. (2016). Modern governance challenges in education. In T. Burns, \& F. Köster (Eds.), Governing education in a complex world, http://dx.doi.org/10.1787/9789264255364-3-en.

Carter, C., \& Lawn, M. (Eds.). (2015). Governing Europe's spaces. Manchester: Manchester University Press.

Connell, R. (2007). Southern theory: The global dynamics of knowledge in social science. Cambridge: Polity Press.

Connell, R. (2013). The neoliberal cascade and education: An essay on the market agenda and its consequences. Critical Studies in Education, 54(2), 99-112. https://doi.org/10.1080/17508 487.2013.776990. 
Dale, R. (2000). Globalisation and education. Education Theory, 50(4), 427-449.

Delvaux, B., \& Mangez, E. (2008). Towards a sociology of the knowledge-policy relation, KnowandPol, Literature synthesis. www.knowandpol.eu. Accessed 10 July 2018.

Demszky, A., \& Nassehi, A. (2014). The role of knowledge in scientific policy advice. In T. Fenwick, E. Mangez, \& J. Ozga (Eds.), Governing knowledge: Comparison, knowledge-based technologies and expertise in the regulation of education (pp. 113-127). London: Routledge.

Department for Education (DfE). (2010). Academies act. http://www.legislation.gov.uk/ukpga/2010/32/ contents. Accessed 4 Feb 2018.

Department for Education (DfE). (2015). Governance handbook: For trustees of academies and multiacademy trusts and governors of maintained schools. [Online]. https://goo.gl/qk1EqN. Accessed 4 Feb 2017.

Department for Education (DfE). (2016). Educational excellence everywhere. https://assets.publishing .service.gov.uk/government/uploads/system/uploads/attachment_data/file/508447/Educational_ Excellence_Everywhere.pdf. Accessed 4 June 2018.

Fazekas, M., \& Burns, T. (2012). Exploring the complex interaction between governance and knowledge in education. In OECD education working papers, no. 67. OECD Publishing. http://dx.doi. org/10.1787/5k9flcx21340-en.

Gewirtz, S., \& Ozga, J. (1990). Partnership, pluralism and education policy: A reassessment.Journal of Education Policy, 5(1), 37-48.

Green, A. (1990). Education and State Formation: The rise of education systems in England, France and the USA. London: Macmillan.

Grek, S. (2012). What PISA knows and can do: Studying the role of national actors in the making of PISA. European Education Research Journal, 11(2), 244-255.

Grek, S. (2017). Socialisation, learning and the OECD's reviews of national policies for education: The case of Sweden. Critical Studies in Education, 58(3), 295-310.

Grek, S., Lawn, M., Lingard, B., Ozga, J., Rinne, R., Segerholm, C., et al. (2009). National policy brokering and the construction of the European education space in England, Sweden. Finland and Scotland. Comparative Education, 45(1), 5-22.

Grek, S., \& Lindgren, J. (Eds.). (2014). Governing by inspection: school inspection in Scotland, Sweden and England. Oxford: Routledge.

Grek, S., \& Ozga, J. (2010). Re-inventing public education: The new role of knowledge in education policy making public policy and administration, 25(3), 271-288.

Grek, S., \& Ozga, J. (2012). Governing through learning: School self-evaluation as a knowledge-based regulatory tool. Recherches sociologiques et anthropologiqes, 2012(2), 83-103.

Grundmann, R., \& Stehr, N. (2012). The power of scientific knowledge. Cambridge: Cambridge University Press.

Higgins, V., \& Larner, W. (Eds.). (2012). Calculating the social: Standards and the reconfiguration of governing. London: Palgrave.

Institute for Public Policy Research (IPPR). (2001). Building better partnerships. London: IPPR.

Laegrid, P., \& Mattei, P. (2013). Introduction: Reforming the welfare state and the implications for accountability in a comparative perspective. International Review of Administrative Sciences, 79(2), 197-201.

Lascoumes, P., \& le Gales, P. (2007). Introduction: Understanding public policy through its instruments-From the nature of instruments to the sociology of public policy instrumentation. Governance, 20(1), 1-21.

Lawn, M. (1996). Modern times. Lewes: Falmer.

Lawn, M. (2013). A systemless system: Designing the disarticulation of english state education. European Educational Research Journal, 12(2), 231-241.

Lawn, M., \& Lingard, B. (2002). Constructing a european policy space in educational governance: The role of transnational policy actors. European Educational Research Journal,1(2), 290-307.

Lawn, M., \& Normand, R. (2015). Shaping of European education: Interdisciplinary approaches. London: Routledge.

Lawn, M., \& Ozga, J. (1986). Schoolwork: Interpreting the labour process of teaching. British Journal of Sociology of Education, 9(3), 323-336.

Manin, B. (1997). The principles of representative government. Cambridge: Cambridge University Press.

Mausethagen, S. (2013). Accountable for what and to whom? Changing representations and new legitimation discourses among teachers under increased external control. Journal of Educational Change, 14(4), 423-444. 
Newman, J., \& Clarke, J. (2009). Publics, politics and power: Remaking the public in public services. London: Sage.

Normand, R. (2016). The changing epistemic governance of european education. Rotterdam: Springer.

Novoa, A., \& Yariv-Maschal, T. (2003). Comparative research in education: A mode of governance or a historical journey? Comparative Education, 39(4), 423-438.

Olssen, M., \& Peters, M. (2005). Neoliberalism, higher education and the knowledge economy: From the free market to knowledge capitalism. Journal of Education Policy, 20(3), 313-345.

Ozga, J. (2000). Policy research in educational settings. Buckingham: Open University Press.

Ozga, J. (2009). Governing education through data in England: From regulation to self-evaluation. Special Issue of Journal of Education Policy, 24(2), 149-163.

Ozga, J. (2016). Trust in numbers? Digital education governance and the inspection process. European Educational Research Journal, 15(1), 69-81.

Ozga, J. (2017). Education and nationalism in Scotland. In K. Kantasalmi \& G. Holm (Eds.), The state, schooling and identity. Singapore: Springer.

Ozga, J. (2019). Governing and knowledge: Theorising the relationship. In R. Langer \& T. Brusemeister (Eds.), Handbuch der Governance Theorien. Frankfurt: Springer.

Ozga, J., \& Lingard, B. (Eds.). (2007). Introduction. In The Routledge reader in education policy and politics. London: Routledge.

Ozga, J., Dahler-Larsen, P., Segerholm, C., \& Simola, H. (Eds.). (2011). Fabricating quality in education: Data and governance in Europe. London: Routledge.

Piattoeva, N. (2014). Elastic numbers: National examinations data as a technology of government. Journal of Education Policy, 30(3), 316-334.

Piattoeva, N. (2015). Power as translation in the global governance of education. In M. Lawn \& R. Normand (Eds.), Shaping of European education: Interdisciplinary approaches. London: Routledge.

Ranson, S. (2003). Public accountability in the age of neo-liberal governance. Journal of Education Policy, 18(5), 459-480.

Rose, N., \& Miller, P. (2010). Political power beyond the state: Problematics of government. British Journal of Sociology, 61(Supplement 1), 271-303.

Shipman, M. (1984). Education as a public service. London: Harper and Row.

Shiroma, E. O. (2014). Expert consultants and knowledge production. In T. Fenwick, E. Mangez, \& J. Ozga (Eds.), Governing knowledge: Comparison, knowledge-based technologies and expertise in the regulation of education (World Yearbook of Education 2014) (pp. 101-113). London: Routledge.

Stitzlein, S. (2015). Addressing educational accountability and political legitimacy with citizen responsibility. Educational Theory, 65(5), 563-580.

Stone, D. (2013). Knowledge actors and transnational governance. Basingstoke: Palgrave MacMillan.

Tan, C. (2017). The culture of education policy making: Curriculum reform in Shanghai. Critical Studies in Education, 53(2), 153-167.

Williams, R.(1988). Keywords: A vocabulary of culture and society. London: Croom Helm.

Williamson, B. (2017). Big data and education. London: Sage.

Wood, S. H. (1946). The structure of english education. Phi Delta Kappan 27/9 May 267-275.

Yanow, D. (2011). A policy ethnographer's reading of policy anthropology. In C. Shore, S. Wright, \& D. Pero (Eds.), Policy worlds. Oxford: Berghahn Books.

Publisher's Note Springer Nature remains neutral with regard to jurisdictional claims in published maps and institutional affiliations. 